\title{
Hubungan Karakteristik Ibu Dengan Tingkat Pengetahuan Tentang Menopause Di Desa Giri Sasak Kuripan Selatan Kabupaten Lombok Barat
}

\author{
Siti Maryam ${ }^{1 *}$, Dita Retno Pratiwi ${ }^{1)}$ \\ Email : sitiwafiqri@gmail.com \\ 1) Program Studi D III Kebidanan, Universitas Qamarul Huda Badaruddin, NTB, Indonesia
}

\begin{abstract}
Pre menopause is a problem for women which can be caused by a lack of knowledge about menopause, which causes mothers to feel anxious about menopause. Objective: to determine the relationship between maternal characteristics and the level of knowledge about menopause in Giri Sasak Kuripan Selatan Village, West Lombok Regency. This study used a descriptive correlational analytic design with a cross sectional approach. Population of women aged 35-59 years in Giri Sasak Kuripan Selatan Village, West Lombok Regency. The sampling technique uses total sampling with a sample of 69 people. Data collection using a questionnaire. The study was conducted on 2019. Data analysis using Kendall Tau. the characteristics of respondents most respondents aged an average of 35-45 years (69.6\%), worked (62.3\%), had a high school / vocational high school education (58.0\%), a moderate level of knowledge $(52.2 \%)$. Kendall Tau correlation test results age with the level of knowledge about menopause obtained a CC value of 0.257 (low) with a p value of 0.026 , education with a level of knowledge about menopause obtained a CC value of 0.589 (moderate) with a p value of 0.000 and work with the level of knowledge about menopause obtained a CC value of 0.493 (moderate) with a $\mathrm{p}$ value of 0.000 . There is a relationship between age, education, mother's occupation with the level of knowledge about menopause in Giri Sasak Kuripan Selatan Village, West Lombok Regency.
\end{abstract}

Keywords: characteristics, knowledge, menopause.

\begin{abstract}
ABSTRAK
Pre menopause menjadi masalah bagi wanita yang dapat disebabkan karena kurangnya pengetahuan tentang menopause sehingga menyebabkan ibu merasa cemas menghadapi menopause. Tujuan untuk mengetahui hubungan karakteristik ibu dengan tingkat pengetahuan tentang menopause di Desa Giri Sasak Kuripan Selatan Kabupaten Lombok Barat. Penelitian ini menggunakan desain diskriptif analitik korelasional dengan pendekatan cross sectional. Populasi ibu usia 35-59 tahun di di Desa Giri Sasak Kuripan Selatan Kabupaten Lombok Barat. Teknik sampling menggunakan total sampling dengan jumlah sampel 69 orang. Pengumpulan data menggunakan kuesioner. Penelitian dilaksanakan pada Tahun 2019. Analisis data menggunakan Kendall Tau. Karakteristik responden sebagian besar responden berumur ratarata 35-45 tahun $(69.6 \%)$, bekerja $(62,3 \%)$, berpendidikan menengah SMA/SMK $(58,0 \%)$, tingkat pengetahuan sedang $(52,2 \%)$. Tabel hasil uji korelasi Kendall Tau umur dengan tingkat pengetahuan tentang menopause diperoleh nilai CC sebesar 0.257 (rendah) dengan nilai $\mathrm{p}$ value sebesar 0.026 , pendidikan dengan tingkat pengetahuan tentang menopause diperoleh nilai CC sebesar 0.589 (sedang) dengan nilai $\mathrm{p}$ value sebesar 0.000 dan pekerjaan dengan tingkat pengetahuan tentang menopause diperoleh nilai CC sebesar 0.493 (sedang) dengan nilai $\mathrm{p}$ value sebesar 0.000 . Ada hubungan antara umur, pendidikan, pekerjaan ibu dengan tingkat pengetahuan tentang menopause di Desa Giri Sasak Kuripan Selatan Kabupaten Lombok Barat.
\end{abstract}

Kata kunci: karakteristik, tingkat pengetahuan, menopause. 


\section{A. PENDAHULUAN}

Menopause merupakan suatu gejala dalam kehidupan wanita yang ditandai dengan berhentinya siklus menstruasi. Menopause adalah fase alami dalam kehidupan setiap wanita yang menandai berakhirnya masa subur. Menopause seperti halnya menarche dan kehamilan dianggap sebagai peristiwa yang sangat berarti bagi kehidupan wanita. Menarche pada remaja wanita, menunjukkan mulai diproduksinya hormon estrogen, sedang menopause terjadi karena ovarium tidak menghasilkan atau tidak memproduksi hormon estrogen [1].

Sejalan dengan proses ketautan yang pasti dialami setiap orang, terjadi pula kemunduran fungsi organ-organ tubuh termasuk salah satu organ reproduksi wanita, yaitu ovarium. Terganggunya fungsi ovarium menyebabkan berkurangnya produksi hormon estrogen, dan ini akan menimbulkan beberapa penurunan atau gangguan pada aspek fisik-biologis-seksual. Pada sebagian wanita, munculnya gejala atau gangguan fisik sebagai akibat dari berhentinya produksi hormon estrogen, juga akan berpengaruh pada kondisi psikologis, dan sosialnya [1].

Pre menopause menjadi masalah bagi wanita. Kendati hal ini alamiah terjadi pada semua wanita, namun efek sampingnya banyak mempengaruhi keharmonisan rumah tangga bila tidak siap menghadapinya. Penurunan kadar estrogen sering menimbulkan gejala yang sangat menganggu aktivitas kehidupan para wanita bahkan mengancam kebahagian rumah tangga. Gejala tersebut disebut sindroma menopause, sindroma menopause dialami oleh banyak wanita hampir diseluruh dunia, sekitar 70-80\% wanita Eropa, 60\% di Amerika, 57\% di Malaysia, $18 \%$ di Cina dan $10 \%$ di Jepang dan Indonesia [1].

Berdasarkan studi pendahuluan di Desa Giri Sasak Kecamatan Kuripan Selatan Kabupaten Lombok Barat diperoleh bahwa 4 ibu yang diwawancarai tentang tingkat pengetahuan menopause terdapat 3 dari 4 orang ibu yang tidak mengetahui tentang menopause sehingga ibu merasa cemas menghadapi menopause dan karakteristik ibu, 3 orang ibu yang pendidikan menengah (SMA) dan 1 orang berpendidikan dasar (SMP), 2 orang bekerja sebagai Ibu Rumah Tangga, 1 orang bekerja sebagai guru TK dan 1 bekerja sebagai pedagang warung dan 1 ibu berumur 40 tahun, 1 orang berumur 35 tahun, 1 orang berumur 46 tahun dan 1 orang berumur 50 tahun dalam kaitannya dengan hal tersebut peniliti tertarik meneliti tentang "Hubungan Karakteristik Ibu

Dengan Tingkat Pengetahuan Tentang Menopause Di Desa Giri Sasak Kuripan Selatan Kabupaten Lombok Barat".

\section{B. METODE PENELITIAN}

Desain penelitian yang digunakan oleh peneliti adalah cross sectional yaitu suatu penelitian di mana variabel yang termasuk faktor resiko yaitu karakteristik ibu dan variabel yang termasuk efek yaitu tingkat pengetahuan tentang menopause diobservasi sekaligus pada waktu yang sama. [2]

Sampel adalah sebagian atau wakil populasi yang diteliti [3]. Sampel penelitian adalah sebagian dari jumlah dan karakteristik yang dimiliki oleh populasi tersebut. Sampel penelitian ini adalah semua ibu usia 35-59 tahun sebanyak 69 orang ibu yang berada di Desa Giri Sasak Kuripan Selatan Kabupaten Lombok Barat, teknik sampling yang digunakan adalah teknik non probability sampling, dengan kriteria inklusi dan ekslusi yaitu :

Kriteria inklusi dalam penelitian ini adalah:

1) Bersedia menjadi responden

2) Bisa baca dan tulis

3) Tercatat sebagai penduduk Desa Giri Sasak Kecamatan Kuripan Selatan Kabupaten Lombok Barat.

C. HASIL DAN PEMBAHASAN

1. Hubungan Karakteristik Umur dengan Tingkat pegetahuan. 
Tabel 1

Hubungan karakteristik umur ibu dengan tingkat pengetahuan tentang menopause di Desa Giri Sasak Kecamatan Kuripan Selatan Kabupaten Lombok Barat.

\begin{tabular}{|c|c|c|c|c|c|c|c|c|c|c|}
\hline \multirow{3}{*}{ Umur } & \multicolumn{6}{|c|}{ Tingkat Pengetahuan } & \multirow{2}{*}{\multicolumn{2}{|c|}{ Total }} & \multirow{3}{*}{$\mathrm{CC}$} & \multirow{3}{*}{$\begin{array}{c}\mathrm{p} \\
\text { value }\end{array}$} \\
\hline & \multicolumn{2}{|c|}{ Tinggi } & \multicolumn{2}{|c|}{ Sedang } & \multicolumn{2}{|c|}{ Rendah } & & & & \\
\hline & $\mathrm{n}$ & $\%$ & $\mathrm{n}$ & $\%$ & $\mathrm{n}$ & $\%$ & $\mathrm{n}$ & $\%$ & & \\
\hline $35-45$ tahun & 16 & 23.2 & 24 & 34.8 & 8 & 11.6 & 48 & 69.6 & & \\
\hline$>45-59$ tahun & 2 & 2.9 & 12 & 17.4 & 7 & 10.1 & 21 & 30.4 & & \\
\hline Total & 18 & 26.1 & 36 & 52,2 & 15 & 21.7 & 69 & 100 & & \\
\hline
\end{tabular}

Berdasarkan analisis di atas diketahui sebagian besar bahwa mayoritas responden memiliki pengetahuan pada kategori sedang dengan umur 35-45 tahun sebanyak 24 responden (34.8\%) dan yang paling sedikit adalah responden yang pengetahuannya tinggi dengan umur >45-59 tahun sebanyak 2 responden $(2.9 \%)$.

Untuk mengetahui apakah ada hubungan antara karakteristik umur ibu dengan tingkat pengetahuan tentang menopause di Desa Giri Sasak Kecamatan Kuripan Selatan Kabupaten Lombok Barat, dapat dilihat pada nilai $p$ value 0.026 pada tabel 4.2 diatas. Hasil pengujian menunjukkan bahwa nilai $p$ value 0.026 ( $\mathrm{p}<$ 0.05 ) yang berarti ada hubungan sebesar 0.257 (rendah) antara karakteristik umur ibu dengan tingkat pengetahuan ibu tentang menopause di

Desa Giri Sasak Kecamatan Kuripan Selatan Kabupaten Lombok Barat.

2. Hubungan Karakteristik Pendidikan dengan Tingkat Pengetahuan.

Berdasarkan analisis Tabel 2 diketahui sebagian besar bahwa mayoritas responden memiliki pengetahuan pada kategori sedang dengan pendidikan menengah sebanyak 30 responden $(43.5 \%)$ dan yang paling sedikit adalah responden yang pengetahuannya tinggi dengan pendidikan dasar sebanyak 1 responden $(1.4 \%)$.

Untuk mengetahui apakah ada hubungan antara karakteristik pendidikan ibu dengan tingkat pengetahuan tentang menopause di Desa Giri Sasak Kecamatan Kuripan Selatan Kabupaten Lombok Barat, dapat dilihat pada nilai $p$ value 0.000 pada tabel 2 .

\section{Tabel 2}

Hubungan karakteristik pendidikan ibu dengan tingkat pengetahuan tentang menopause di Desa Giri Sasak Kecamatan Kuripan Selatan Kabupaten Lombok Barat.

\begin{tabular}{|c|c|c|c|c|c|c|c|c|c|c|}
\hline \multirow{3}{*}{ Pendidikan } & \multicolumn{6}{|c|}{ Tingkat Pengetahuan } & \multirow{2}{*}{\multicolumn{2}{|c|}{ Total }} & \multirow{3}{*}{$\mathrm{CC}$} & \multirow{3}{*}{$\mathrm{p}$ value } \\
\hline & \multicolumn{2}{|c|}{ Tinggi } & \multicolumn{2}{|c|}{ Sedang } & \multicolumn{2}{|c|}{ Rendah } & & & & \\
\hline & $\mathrm{n}$ & $\%$ & $\mathrm{n}$ & $\%$ & $\mathrm{n}$ & $\%$ & $\mathrm{n}$ & $\%$ & & \\
\hline Dasar & 1 & 1.4 & 3 & 4,3 & 8 & 11.6 & 12 & 17,4 & & \\
\hline Menengah & 4 & 5.8 & 30 & 43.5 & 6 & 8.7 & 40 & 58 & 0.589 & 0.000 \\
\hline Tinggi & 13 & 18.8 & 3 & 4,3 & 1 & 1.4 & 17 & 24.6 & & \\
\hline Total & 18 & 26. & 36 & 52,2 & 15 & 21.7 & 69 & 100 & & \\
\hline
\end{tabular}


Hasil pengujian menunjukkan bahwa nilai $\mathrm{p}$ value $0.000(\mathrm{p}<0.05)$ yang berarti ada hubungan sebesar 0.589 (sedang) antara karakteristik pendidikan ibu dengan tingkat pengetahuan ibu tentang menopause di Desa Giri Sasak Kecamatan Kuripan Selatan Kabupaten Lombok Barat.

\section{Hubungan Karakteristik Pekerjaan dengan Tingkat Pengetahuan}

Berdasarkan analisis Tabel 3 diketahui sebagian besar bahwa mayoritas responden memiliki pengetahuan pada kategori sedang dengan status bekerja sebanyak 27 responden (39.1\%) dan yang paling sedikit adalah responden yang pengetahuannya rendah dengan status bekerja sebanyak 1 responden (1.4\%).

Untuk mengetahui apakah ada hubungan antara karakteristik pekerjaan dengan tingkat pengetahuan tentang menopause di Desa Giri Sasak Kecamatan Kuripan Selatan Kabupaten Lombok Barat, dapat dilihat pada nilai $p$ value 0.000 pada tabel 4.2 diatas. Hasil pengujian menunjukkan bahwa nilai $\mathrm{p}$ value 0.000 ( $\mathrm{p}<$ 0.05 ) yang berarti ada hubungan sebesar 0.493 (sedang) antara karakteristik pekerjaan ibu dengan tingkat pengetahuan ibu tentang menopause di Desa Giri Sasak Kecamatan Kuripan Selatan Kabupaten Lombok Barat.

Secara umum hasil penelitian menunjukkan bahwa tingkat pengetahuan ibu di Desa Giri Sasak Kecamatan Kuripan Selatan Kabupaten Lombok Barat Tahun 2019 mayoritas responden termasuk pada kategori pengetahuan sedang sebanyak 36 responden (52.2\%). Hal ini sesuai dengan pendapat Notoatmodjo pengetahuan adalah segala sesuatu yang diketahui dan diperoleh secara sengaja dan tidak sengaja melalui penginderaan terhadap suatu objek. Pengetahuan tentang menopause dapat diketahui melalui buku petunjuk, petugas kesehatan, media massa, media elektronik dan sebagainya [4].

Hasil penelitian menunjukkan ada hubungan yang rendah karakteristik umur ibu dengan tingkat pengetahuan tentang menopause di Desa Giri Sasak Kecamatan Kuripan Selatan Kabupaten Lombok Barat. Hal ini sesuai dengan pendapat Proverawati [1], seiring dengan peningkatan usia, banyak terjadi proses perkembangan dan pertumbuhan pada manusia. Namun suatu saat perkembangan dan pertumbuhan itu akan terhenti pada suatu tahapan, sehingga berikutnya akan terjadi banyak perubahan yang terjadi pada fungsi tubuh manusia. Perubahan tersebut biasanya terjadi proses menua, karena pada proses ini banyak terjadi perubahan fisik maupun psikologis.

Adapun hasil yang menunjukkan bahwa umur ibu 35-45 tahun memiliki tingkat pengetahuan sedang sebesar 24 responden $(34.8 \%)$. Hal ini karena pengalaman, dimana pengalaman adalah sesuatu yang pernah dialami seseorang akan menambah pengetahuan tentang sesuatu yang bersifat nonformal termasuk tingkat pengetahuan tentang menopause.

Tabel 3

Hubungan karakteristik pekerjaan ibu dengan tingkat pengetahuan tentang menopause di Desa Giri Sasak Kecamatan Kuripan Selatan Kabupaten Lombok Baratt Tahun 2019

\begin{tabular}{|c|c|c|c|c|c|c|c|c|c|c|c|}
\hline \multirow{3}{*}{ No } & \multirow{3}{*}{ Pekerjaan } & \multicolumn{6}{|c|}{ Tingkat Pengetahuan } & \multirow{2}{*}{\multicolumn{2}{|c|}{ Total }} & \multirow{3}{*}{$\mathrm{CC}$} & \multirow{3}{*}{$\mathrm{p}$ value } \\
\hline & & \multicolumn{2}{|c|}{ Tinggi } & \multicolumn{2}{|c|}{ Sedang } & \multicolumn{2}{|c|}{ Rendah } & & & & \\
\hline & & $\mathrm{n}$ & $\%$ & $\mathrm{n}$ & $\%$ & $\mathrm{n}$ & $\%$ & $\mathrm{n}$ & $\%$ & & \\
\hline 1 & Bekerja & 15 & 21.7 & 27 & 39.1 & 1 & 1.4 & 43 & 62,3 & & \\
\hline 2 & Tidak bekerja & 3 & 4.3 & 9 & 13.0 & 14 & 20.3 & 26 & 37,7 & & \\
\hline & Total & 18 & 26.1 & 36 & 52,2 & 15 & 21.7 & 69 & 100 & & \\
\hline
\end{tabular}


Sedangkan umur $>45-59$ tahun dengan tingkat pengetahuan rendah sebanyak 7 responden $(10.1 \%)$ [4].

Hal ini karena sumber informasi yang di dapat oleh ibu kurang seperti yang diungkapkan oleh Notoatmodjo [4] seseorang yang mempunyai sumber informasi yang lebih banyak akan mempunyai pengetahuan yang lebih luas. Sedangkan umur >45-59 tahun dengan tingkat pengetahuan tinggi sebanyak 2 responden $(2.9 \%)$ dikarenakan kurangnya pemahaman tentang menopause seperti yang diungkapkan oleh Notoatmodjo memahami adalah kemampuan menjelaskan secara benar tentang suatu objek yang diketahui dan dapat mempresentasikan suatu materi tersebut secara benar [4]. Dimana sesuai dengan pendapat Santrock tidak ada batasan umur yang pasti sesungguhnya setiap wanita mengalaminya pada umur tertentu, setelah masa kesempurnaan berakhir [5]. Hal ini sesuai dengan Braam dkk, yang menyatakan bahwa sebagian besar wanita, menopause terjadi pada umur antara 45-55 tahun [6].

Hasil penelitian menunjukkan bahwa ada hubungan yang rendah karakteristik pendidikan ibu dengan tingkat pengetahuan tentang menopause di Desa Giri Sasak Kecamatan Kuripan Selatan Kabupaten Lombok Barat dibuktikan dengan koefisien korelasi Kenddal Tau $(t)$ diperoleh nilai sebesar 0.589 (sedang) dan $p$ value 0.000 . Hal ini salah satunya disebabkan karena masalah sosial ekonomi sehingga responden masih memiliki tingkat pendidikan menengah dimana seperti yang diungkapkan oleh Kasdu wanita yang berpendidikan lebih tinggi, hal ini sangat dimungkinkan oleh karena wanita lebih mudah mendapatkan informasi dari fasilitas seperti majalah, koran dan buku kesehatan, akses internet dll, dalam memperoleh pengetahuan tentang menopause [7]. pendidikan merupakan pengalaman yang memberikan pengalaman dan penyesuaian bagi seseorang yang menyebabkan orang tersebut berkembang, seseorang yang mengalami proses pendidikan dalam dirinya akan terjadi interaksi antara kecerdasan, pengertian dan pengalaman yang kemudian dinyatakan dalam sikap dan tingkah laku. [7]. Dimana faktor sosial ekonomi juga mempegaruhi keadaan ibu pada saat mengalami gejala menopause seperti yang diungkapkan oleh Pakasi bahwa keadaan sosial ekonomi mempengaruhi faktor fisik, kesehatan dan pendidikan [8].

Hasil penelitian menunjukkan bahwa ada hubungan yang rendah karakteristik pekerjaan ibu dengan tingkat pengetahuan tentang menopause di Desa Giri Sasak Kecamatan Kuripan Selatan Kabupaten Lombok Barat dibuktikan dengan koefisien korelasi Kenddal Tau ( $t$ ) diperoleh nilai sebesar 0.493 (sedang) dan $p$ value 0.000 . Hal ini sesuai yang diungkapkan oleh Notoatmodjo [9] kesempatan mengembangkan diri bagi wanita bekerja jika dihubungkan dengan efktifitas mendapatkan informasi sangatlah tergantung dengan jenis atau status pekerjaannya. Ada sebagian jenis pekerjaan yang justru menghambat pengembangan diri wanita, yang biasa adalah jenis pekerjaan rutunitas dan berstatus penghasilan rendah. Hal ini yang muncul akibat bekerja adalah kaitannya dengan waktu dan linkungan tempat wanita berinteraksi karena dari lingkunganlah seseorang dapat memperoleh berbagai informasi termasuk informasi tentang menopause. [10] seperti yang diungkapkan oleh Aswati (2017) pada dasarnya peran utama wanita dalam keluarga adalah berperan sebagai ibu rumah tangga seperti memasak, mengasuh anak, dan sebagainya. Hal ini merupakan suatu pekerjaan produktif yang secara tidak langsung menghasilkan pendapatan, karena pekerjaan itu memungkinkan anggota keluarga lainnya untuk mendapatkan penghasilan secara langsung. [11].

Hasil penelitian ini tidak jauh berbeda dengan penelitian yang dilakukan oleh Ary dengan hasil penelitian terdapat perbedaan yang bermakna mengenai tingkat pengetahuan tentang klimakterium antara wanita bekerja dan tidak bekerja di Desa nganglian Wadaslintang 
Wonosobo Jawa Tengah. Meneliti tentang wanita bekerja dan tidak bekerja [12].

\section{KESIMPULAN}

Ada hubungan karakteristik ibu dengan tingkat pengetahuan tentang menopause di Desa Giri Sasak Kecamatan Kuripan Selatan Kabupaten Lombok Barat. Tingkat pengetahuan ibu tentang menopause di Desa Giri Sasak Kecamatan Kuripan Selatan Kabupaten Lombok Barat adalah sedang (52.2\%). Ada hubungan yang rendah (0.257) antara karakteristik umur ibu dengan tingkat pengetahuan tentang menopause di Desa Giri Sasak Kecamatan Kuripan Selatan Kabupaten Lombok Barat. Ada hubungan yang sedang (0.589) antara karakteristik pendidikan ibu dengan tingkat pengetahuan tentang menopause di Desa Giri Sasak Kecamatan Kuripan Selatan Kabupaten Lombok Barat. Ada hubungan yang sedang (0.493) antara karakteristik pekerjaan ibu dengan tingkat pengetahuan tentang menopause di Desa Giri Sasak Kecamatan Kuripan Selatan Kabupaten Lombok Barat.

\section{DAFTAR PUSTAKA}

[1] Proverawati, A, MPH.2010. Menopause dan Sindrome Premenopause. Muha Medika. Yogyakarta.

[2] Notoatmodjo, S. (2010). Metodologi Penelitian Kesehatan.Jakarta: Rineka Cipta.

[3] Arikunto. (2010). Metode penelitian. Jakarta: Rineka Cinta.

[4] Notoatmodjo, S.2007. Promosi Kesehatan dan Ilmu Perilaku. Rineka Cipta. Jakarta

[5] Santrock, John W (2014). Psikologi Pendidikan.Jakarta: Salemba Humanika

[6] Braam, W.2000. 100 Pertanyaan Mengenai Menopause. Terjemahan oleh Sri Moersadik. Sinar Harapan. Jakarta

[7] Kasdu, D (2008). Solusi Problem Wanita Dewasa. Jakarta: Puspa Swara, Anggoru IKAPI.

[8] Pakasi. 2000. Menopause Masalah dan Penanggulangannya. Fakultas Kedokteran Universitas Indonesia. Jakarta

[9] Notoatmodjo, S.2005. Pendidikan dan Perilaku Kesehatan. Rineka Cipta. Jakarta
[10] Aswati, S (2017). Studi Analisis Model Rapid Application Development Dalam Pengembangan System Informasi. Jurnal Matrik, ISSN: 1858-4144, 16(2),20-27

[11] Ari,S.2006. Perbedaan Tingkat Pengetahuan Tentang Klimakterium Dengan Sikap Menghadapi Menopause Antara Wanita Bekerja dan Tidak Bekerja. Laporan Penelitian Fakultas Kesehatan. Universitas Gadjah Mada. Yogyakarta (tidak dipublikasikan) 